\title{
IMPACT OF COVID-19 ON THE PHYSICAL ACTIVITY AND WELL-BEING OF HUNGARIAN ATHLETES AND SPORTS PROFESSIONALS
}

\section{WPEYW COVID-19 NA AKTYWNOŚĆ FIZYCZNĄ I DOBROSTAN WĘGIERSKICH SPORTOWCÓW I SPECJALISTÓW SEKTORA SPORTOWEGO}

\author{
Tünde Szabó ${ }^{1(A, B, C, D, E, F)}$, Miklós Stocker ${ }^{2(A, B, C, D, E, F)}$, Pongrác Ács ${ }^{3(A, D)}$, Kata Morvay-Sey ${ }^{3(A, D)}$, \\ Ágnes Pálvölgyi ${ }^{3(\mathrm{~A}, \mathrm{D})}$, Tamás Laczkóo ${ }^{3(\mathrm{C}, \mathrm{D}, \mathrm{E}, \mathrm{F})}$
}

${ }^{1}$ Ministry of Human Capacities, Budapest, Hungary

${ }^{2}$ Department of Business Studies, Corvinus University of Budapest, Hungary

${ }^{3}$ Faculty of Health Sciences, University of Pécs, Hungary

Authors' contribution Wkład autorów:

A. Study design/planning zaplanowanie badań B. Data collection/entry zebranie danych

C. Data analysis/statistics dane - analiza i statystyki D. Data interpretation interpretacja danych E. Preparation of manuscript przygotowanie artykułu F. Literature analysis/search wyszukiwanie i analiza literatury G. Funds collection zebranie funduszy

\section{Summary}

Background. The COVID-19 pandemic had a significant effect on regular activities and lifestyles in Hungary in the second quarter of 2020. In this study, we identify the physical activity and mental well-being changes in the Hungarian sport sector.

Material and methods. A questionnaire, which included internationally validated items, was created to survey members of the sporting sector in Hungary. In June 2020, we obtained 840 valid responses, the age and gender profile of which were closely representative of the overall population. The results were analyzed with descriptive and inferential statistics.

Results. Physical activity during the COVID-19 pandemic changed significantly $(p<0.001)$ in the Hungarian sport sector, decreasing by $166 \pm 1128$ minutes (mean $\pm S D$ ) per week, on average. Women (-286 \pm 980 weekly minutes) and children's ( $-304 \pm 951$ weekly minutes) physical activity decreased the most, whereas that of middle-aged $(-83 \pm 1024$ weekly minutes) and graduates $(-99 \pm 982$ weekly minutes) decreased the least. Greater well-being was felt during the pandemic by those who were either more physically active, or could even increase their physical activity. Conclusions. Even in the sport sector, the more physically active people are, the greater their well-being. Therefore, promotion of physical activity becomes even more important in challenging times.

Keywords: COVID-19, physical activity, mental well-being, sport sector

\section{Streszczenie}

Wprowadzenie. Pandemia COVID-19 miała znaczący wpływ na regularna działalność i styl życia na Węgrzech w drugim kwartale 2020 roku. Niniejsze badanie posłużyło określeniu zmian dotyczących aktywności fizycznej i dobrostanu umysłowego w węgierskim sektorze sportowym.

Materiał i metody. W celu przebadania członków węgierskiego sektora sportowego stworzono kwestionariusz zawierający elementy uznane międzynarodowo. W czerwcu 2020 roku zebrano 840 właściwych odpowiedzi. Na ich podstawie ustalono, że wynik jest zbliżony do reprezentatywnego w zakresie wieku i płci całej populacji. Rezultaty zostały przeanalizowane za pomocą statystyki opisowej i inferencyjnej.

Wyniki. Aktywność fizyczna członków węgierskiego sektora sportowego podczas pandemii COVID-19 uległa znaczącej zmianie $(\mathrm{p}<0,001)$, ponieważ spadła średnio o $166 \pm 1128$ minut (mean \pm SD) na tydzień. Najwięsszy spadek zaobserwowano $w$ aktywności fizycznej dzieci $(-304 \pm 951$ minut tygodniowo) i kobiet $(-286 \pm 980$ minut tygodniowo), podczas gdy osoby w średnim wieku $(-83 \pm 1024$ minut tygodniowo) i absolwenci $(-99 \pm 982$ minut tygodniowo) ograniczyli swoja aktywność fizyczna w najmniejszym stopniu. Osoby, które były bardziej aktywne fizycznie albo mogły zwiększyć swoją aktywność, odczuwały podczas pandemii największy dobrostan.

Wnioski. Określono, że - nawet w sektorze sportowym - im wyższa aktywność fizyczna, tym większy odczuwalny dobrostan jego członków. Promocja aktywności fizycznej staje się zatem w trudnych okresach szczególnie istotna.

Słowa kluczowe: COVID-19, aktywność fizyczna, dobrostan umysłowy, sektor sportowy
Figures: 1

References: 20

Submitted: 2020 Jun 30

Accepted: 2020 Aug 24

Szabó T, Stocker M, Ács P, Morvay-Sey K, Pálvölgyi A, Laczkó T. Impact of COVID-19 on the physical activity and well-being of Hungarian athletes and sports professionals. Health Prob Civil. 2020; 14(3): 165-173. https://doi.org/10.5114/hpc.2020.98471

Address for correspondence / Adres korespondencyjny: Miklós Stocker, Department of Business Studies, Corvinus University of Budapest, Fővám tér 8, 1093

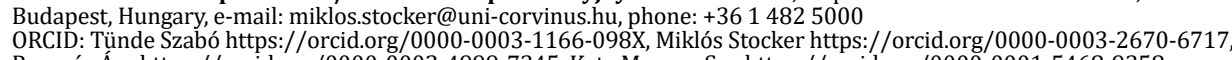

Pongrác Ács https://orcid.org/0000-0002-4999-7345, Kata Morvay-Sey https://orcid.org/0000-0001-5468-9358,

Ágnes Pálvölgyi https://orcid.org/0000-0002-4439-1977, Tamás Laczkó https://orcid.org/0000-0002-5795-760X

Copyright: (C) Pope John Paul II State School of Higher Education in Biała Podlaska, Tünde Szabó, Miklós Stocker, Pongrác Ács, Kata Morvay-Sey, Ágnes Pálvölgyi, Tamás Laczkó. This is an Open Access journal, all articles are distributed under the terms of the Creative Commons Attribution-NonCommercial-ShareAlike 4.0 International (CC BY-NC-SA 4.0) License (http://creativecommons.org/licenses/by-nc-sa/4.0/), allowing third parties to copy and redistribute the material in any medium or format and to remix, transform, and build upon the material, provided the original work is properly cited and states its license. 


\section{Introduction}

The COVID-19 pandemic had a significant effect on regular activities and lifestyles in Hungary in the second quarter of 2020. Schools and universities shifted from in-person to online education, several workplaces shifted to home-office, sport-events were postponed or cancelled, and social distancing became the norm. As a result of all these changes, it was anticipated that the physical activity level of Hungarian people would change as well, which would affect the mental well-being of the population, in turn. As the sport sector was one of the most greatly impacted sectors by the COVID-19 pandemic, in this study we identify the physical activity and mental well-being changes in the Hungarian sport sector.

As excessively intensive training can increase the risk of COVID-19 contamination, training of athletes should be tailored to the "new normal" conditions to maintain their physical fitness, without increasing risk [1]. According to Mann et al. the COVID-19 pandemic has shown that athletes' health protection needs to be viewed in the context of the complex social systems of which they are a part [2]. Therefore in this research we do not only study elite and recreational athletes, but coaches, sports managers, and administrators as well. Mann et al., Parnell et al., and Gallego et al. focused mostly on the postponements of mega events [2-4], however athletes and sport professionals also endured significant lifestyle changes because of those postponements, and other impacts of the COVID-19 pandemic as well.

If physical activity decreases because of lifestyle changes and restrictions caused by the pandemic, this will also impact negatively on the national economy. Physical activity decreases mental problems like depression, cardiovascular related disease such as heart and coronary disease, stroke, hypertension, etc., and increases the motivation of the workforce. Physical inactivity works in the opposite direction, which can result in direct and indirect financial burdens to the national economy [5].

Besides physical activity, the well-being of the members of sport sector is also very important to analyze during the COVID-19 pandemic. Research in the past few months has shed light on the importance of physical activity against the severe (or even deadly) side effects of COVID-19 and its support of the immune system [6,7]. In the time of the pandemic and social distancing, besides physical health, mental and spiritual health also came into focus, and sport is one of the most efficient tools for influencing them [8]. Several studies have shown the positive effect of physical activity and sport on shaping and sustaining mental health and psychological well-being [9-11]. In this study we also identify the relationship between psychological well-being and physical activity during the COVID-19 pandemic in the Hungarian sport sector.

\section{Material and methods}

\section{Participants}

In this study we surveyed Hungarian citizens connected to the sport sector in Hungary. We obtained n=840 valid responses, with 3 additional responses which did not consent to their responses being used for analysis or research purposes.

The classification of respondents by age and gender can be seen in Table 1. During the COVID-19 outbreak the Hungarian Government declared that older generations (65 years old and greater) were at greatest risk, and older generations' physical activity is also very low in Hungary, therefore we focused our research on those below the age of 65 [12].

Table 1. Age and gender of survey respondents and research population

\begin{tabular}{|c|c|c|c|c|c|c|c|c|}
\hline \multirow{2}{*}{$\begin{array}{c}\text { Age } \\
\text { Group }\end{array}$} & Male & Female & Total & $\begin{array}{c}\text { Percentage of } \\
\text { 0-64 Year-Old } \\
\text { Population }\end{array}$ & Male & Female & Total & $\begin{array}{c}\text { Percentage of } \\
\text { 0-64 Year-0ld } \\
\text { Population }\end{array}$ \\
\hline$<14$ & $7.45 \%$ & $7.06 \%$ & $15 \%$ & $17.81 \%$ & $2.62 \%$ & $10.60 \%$ & $13.21 \%$ & $13.84 \%$ \\
\hline $15-29$ & $9.02 \%$ & $8.50 \%$ & $18 \%$ & $21.51 \%$ & $10.60 \%$ & $13.57 \%$ & $24.17 \%$ & $25.31 \%$ \\
\hline $30-49$ & $14.93 \%$ & $14.62 \%$ & $30 \%$ & $36.29 \%$ & $24.17 \%$ & $14.88 \%$ & $39.05 \%$ & $40.90 \%$ \\
\hline $50-64$ & $9.33 \%$ & $10.53 \%$ & $20 \%$ & $24.39 \%$ & $14.64 \%$ & $4.40 \%$ & $19.05 \%$ & $19.95 \%$ \\
\hline $65-84$ & $6.51 \%$ & $10.27 \%$ & $17 \%$ & & $3.81 \%$ & $0.71 \%$ & $4.52 \%$ & \\
\hline $85-$ & $0.49 \%$ & $1.31 \%$ & $2 \%$ & & $0.00 \%$ & $0.00 \%$ & $0.00 \%$ & \\
\hline Total & $47.71 \%$ & $52.29 \%$ & $100.00 \%$ & $100.00 \%$ & $55.83 \%$ & $44.17 \%$ & $100.00 \%$ & $100.00 \%$ \\
\hline
\end{tabular}

Source: Authors' compilation based on [12]. 
The Hungarian population was estimated to be 9,772,756 by the Hungarian Statistical Office in 2019 [13]; the age and gender demographics of this population can be seen in Table 1, as well as those of our sample. The sample proportions (below age 65) are very similar to the respective proportions of the Hungarian population, therefore we treat our sample as close to representative of age and gender.

\section{Procedures}

Primary data were obtained using an online survey. The questionnaire included internationally validated questionnaires, such as WHO-5 or IPAQ, with other independent variables were created to fit the sport sector. The survey was sent to all 88 Hungarian Sport Associations, with their leaders asked to share the survey link with their members. The survey was created in Google Forms, and made available from June $1^{\text {st }}$ to $14^{\text {th }}, 2020$.

\section{Instrument and measures}

The questionnaire comprised 45 questions, of which there were 9 open ended and 36 closed questions. Questions relating to demographic, sport and physical activity, education, as well as the IPAQ, PSS, MAAS, and WHO-5 scales were included in the questionnaire. The current mental well-being of the population was measured using the established WHO-5 Well-being scale; this consists of 5 items, of which we used the 4-factor Likert scale version (0-3). The cumulated score can vary from $0-15$, where higher numbers represent better mental state and well-being. The questionnaire was validated for the Hungarian population in the Hungarostudy research in 2002, and has been used in several age groups and professions to measure mental well-being successfully ever since [14-16].

\section{Ethics and statistics}

The differences of the given variables, depending on the operationalization of the given variable, were calculated with t-test, ANOVA tests, Kruskal-Wallis H-test and independent-samples T tests. The significance level was set at $\mathrm{p}<0.05$ [17]. All data are expressed as mean \pm SD.

All statistical calculations were computed using IBM SPSS Statistics 25, with Microsoft Excel (from Microsoft Office 365 ProPlus) utilized for other calculations.

Our research is based on the license of the Hungarian Scientific and Research Ethics Committee (IV/45992/2020/EKU).

\section{Results}

The respondents $(n=840)$ represent 52 sports in Hungary; a significant group of respondents (n=109) registered more than one sport, therefore their affiliation was coded as multisport.

Table 2 shows the physical activity of elite athletes, recreational athletes, sport professionals, and those who occupy multiple roles in the sport sector.

Physical activity during the COVID-19 pandemic changed significantly $(\mathrm{p}<0.001)$ in the Hungarian sport sector, decreasing by $166 \pm 1128$ minutes per week, on average. However, if we break down the answers to different roles in the sport sector, the picture becomes more sophisticated. Weekly physical activity of elite athletes decreased significantly by an average of $268.3 \pm 1325$ minutes $(p=0.008)$. In the case of recreational athletes, the weekly decrease was also significant at $194.9 \pm 1224$ minutes on average $(p=0.007)$. Professional athletes, however, saw their weekly physical activity decrease by an average of only $8.2 \pm 726$ minutes, a difference which was deemed not statistically significant $(\mathrm{p}=0.862)$, meaning the COVID-19 pandemic did not significantly affect the overall physical activity time of this group. The physical activity of those with multiple roles in the sport sector also decreased significantly by an average $250 \pm 1198$ minutes per week $(p=0.014)$. 
Table 2. Physical activity of elite athletes, recreational athletes, sport professionals, and those with multiple roles in the sport sector

\begin{tabular}{|c|c|c|c|c|c|c|}
\hline \multicolumn{2}{|l|}{ Roles } & $\begin{array}{c}\text { IPAQ Total } \\
\text { Change (minutes/ } \\
\text { week) }\end{array}$ & $\begin{array}{c}\text { IPAQ Total Before } \\
\text { COVID (minutes/ } \\
\text { week) }\end{array}$ & $\begin{array}{c}\text { IPAQ Total During } \\
\text { COVID (minutes/ } \\
\text { week) }\end{array}$ & $\begin{array}{c}\text { IPAQ Intensive } \\
\text { Change (minutes/ } \\
\text { week) }\end{array}$ & $\begin{array}{c}\text { WHO-5 } \\
\text { Well-Being } \\
\text { Total } \\
\end{array}$ \\
\hline \multirow{3}{*}{ Elite Athlete } & Mean & -268.36 & 1371.27 & 1102.91 & -235.17 & 8.56 \\
\hline & $\mathbf{N}$ & 173 & 173 & 173 & 173 & 173 \\
\hline & $\begin{array}{l}\text { Std. } \\
\text { Dev }\end{array}$ & 1325.29 & 1386.77 & 1448.35 & 682.86 & 3.46 \\
\hline \multirow{3}{*}{$\begin{array}{l}\text { Recreational } \\
\text { Athlete }\end{array}$} & Mean & -194.90 & 1044.05 & 849.14 & -135.86 & 8.15 \\
\hline & $\mathbf{N}$ & 288 & 288 & 288 & 288 & 288 \\
\hline & $\begin{array}{l}\text { Std. } \\
\text { Dev }\end{array}$ & 1224.83 & 1536.62 & 1404.89 & 763.44 & 3.02 \\
\hline \multirow{3}{*}{$\begin{array}{c}\text { Sport } \\
\text { Professional }\end{array}$} & Mean & -8.22 & 731.46 & 723.24 & -1.62 & 8.56 \\
\hline & $\mathbf{N}$ & 237 & 237 & 237 & 237 & 237 \\
\hline & $\begin{array}{l}\text { Std. } \\
\text { Dev }\end{array}$ & 726.30 & 877.08 & 811.72 & 388.01 & 3.24 \\
\hline \multirow{3}{*}{$\begin{array}{l}\text { Multiple } \\
\text { Roles }\end{array}$} & Mean & -250.33 & 1027.59 & 777.26 & -60.47 & 8.51 \\
\hline & $\mathbf{N}$ & 142 & 142 & 142 & 142 & 142 \\
\hline & $\begin{array}{l}\text { Std. } \\
\text { Dev }\end{array}$ & 1198.92 & 1469.72 & 970.24 & 462.59 & 3.38 \\
\hline \multirow{3}{*}{ Total } & Mean & -166.73 & 1020.46 & 853.73 & -105.70 & 8.41 \\
\hline & $\mathbf{N}$ & 840 & 840 & 840 & 840 & 840 \\
\hline & $\begin{array}{l}\text { Std. } \\
\text { Dev }\end{array}$ & 1128.66 & 1352.97 & 1211.34 & 616.81 & 3.24 \\
\hline
\end{tabular}

People in different roles in the sport sector reported their well-being very similarly during the COVID-19 pandemic. The average well-being score was $8.41 \pm 3.24$, with the differences under different roles not significant $(\mathrm{p}=0.411)$.

Changes in physical activity and well-being according to different age groups in the sport sector can be seen in Table 3. There were significant differences in the changes in physical activity across the different age groups $(\mathrm{p}=0.003)$. Physical activity of under 14 year olds decreased the most by $304.7 \pm 951$ minutes per week, followed by the 15-29 age group with a weekly decrease on average of 201.7 \pm 1173 minutes. Groups over 50 (50-64 and 65 84 years of age) decreased their physical activity very similarly on average $(191.7 \pm 1441$ and $190.7 \pm 588$ minutes respectively). The least decrease in physical activity was observed 30-49 age group, dropping by an average of only $83 \pm 1024$ minutes. It is interesting, however, that only the $0-14(p=0.001)$ and $15-29$ age groups $(p=0.015)$ had a significant decrease in their physical activity, whilst that of all other age groups $(30-49,50-64,65-84)$ was not statistically significant, likely due to the huge standard deviations ( $\mathrm{p}=0.141 ; \mathrm{p}=0.095 ; \mathrm{p}=0.053)$.

According to well-being scores, there were no significant differences across the different age groups $(p=0.339)$, with the scores ranging from 7.92 (age 65-84) to 8.62 (age 50-64).

Table 3. Physical activity and well-being by age groups in the sport sector

\begin{tabular}{|c|c|c|c|c|c|c|c|}
\hline \multirow{2}{*}{$\begin{array}{c}\text { IPAQ and WHO-5 Scores by Age } \\
\text { Groups }\end{array}$} & $\mathbf{N}$ & Mean & $\begin{array}{c}\text { Std. } \\
\text { Deviation }\end{array}$ & Std. Error & $\begin{array}{c}\text { 95\% Confidence Interval } \\
\text { for Mean }\end{array}$ \\
\cline { 3 - 8 } & & & & & Lower Limit & Upper Limit \\
\hline \multirow{4}{*}{ IPAQ Total Change } & $\mathbf{1 4 4}$ & 111 & -304.77 & 951.07 & 90.27 & -483.67 & -125.88 \\
\cline { 2 - 8 } & $\mathbf{1 5 - 2 9}$ & 203 & -201.68 & 1173.18 & 82.34 & -364.04 & -39.33 \\
\cline { 2 - 8 } & $\mathbf{3 0 - 4 9}$ & 328 & -83.43 & 1024.47 & 56.57 & -194.71 & 27.85 \\
\cline { 2 - 8 } & $\mathbf{5 0 - 6 4}$ & 160 & -191.69 & 1441.75 & 113.98 & -416.80 & 33.42 \\
\cline { 2 - 8 } & $\mathbf{6 5 - 8 4}$ & 38 & -190.66 & 588.21 & 95.42 & -384.00 & 2.68 \\
\cline { 2 - 8 } & $\mathbf{T o t a l}$ & 840 & -166.73 & 1128.66 & 38.94 & -243.17 & -90.29 \\
\hline \multirow{4}{*}{$\begin{array}{l}\text { IPAQ Total Before } \\
\text { COVID (minutes) }\end{array}$} & $\mathbf{1 4 4}$ & 111 & 1010.74 & 1742.61 & 165.40 & 682.95 & 1338.53 \\
\cline { 2 - 8 } & $\mathbf{1 5 - 2 9}$ & 203 & 1221.00 & 1183.23 & 83.05 & 1057.25 & 1384.74 \\
\cline { 2 - 8 } & $\mathbf{3 0 - 4 9}$ & 328 & 897.86 & 1048.63 & 57.90 & 783.95 & 1011.76 \\
\cline { 2 - 8 } & $\mathbf{5 0 - 6 4}$ & 160 & 1009.24 & 1693.66 & 133.90 & 744.79 & 1273.68 \\
\cline { 2 - 8 } & $\mathbf{6 5 - 8 4}$ & 38 & 1083.13 & 1559.91 & 253.05 & 570.40 & 1595.86 \\
\hline
\end{tabular}




\begin{tabular}{|c|c|c|c|c|c|c|c|}
\hline \multirow{6}{*}{$\begin{array}{l}\text { IPAQ Total During } \\
\text { COVID (minutes) }\end{array}$} & $<14$ & 111 & 705.96 & 1426.40 & 135.39 & 437.66 & 974.27 \\
\hline & 15-29 & 203 & 1019.31 & 1319.84 & 92.63 & 836.66 & 1201.97 \\
\hline & $30-49$ & 328 & 814.42 & 1161.38 & 64.13 & 688.27 & 940.58 \\
\hline & $50-64$ & 160 & 817.54 & 913.50 & 72.22 & 674.91 & 960.17 \\
\hline & $65-84$ & 38 & 892.47 & 1403.76 & 227.72 & 431.07 & 1353.88 \\
\hline & Total & 840 & 853.73 & 1211.34 & 41.80 & 771.70 & 935.77 \\
\hline \multirow{6}{*}{$\begin{array}{l}\text { IPAQ Intensive } \\
\text { Change }\end{array}$} & $<14$ & 111 & -225.37 & 853.21 & 80.98 & -385.86 & -64.88 \\
\hline & $15-29$ & 203 & -111.07 & 623.38 & 43.75 & -197.34 & -24.80 \\
\hline & $30-49$ & 328 & -106.80 & 524.22 & 28.95 & -163.75 & -49.86 \\
\hline & $50-64$ & 160 & -13.04 & 617.57 & 48.82 & -109.47 & 83.38 \\
\hline & $65-84$ & 38 & -107.95 & 439.77 & 71.34 & -252.50 & 36.60 \\
\hline & Total & 840 & -105.70 & 616.81 & 21.28 & -147.47 & -63.92 \\
\hline \multirow{6}{*}{$\begin{array}{c}\text { WHO-5 Well-Being } \\
\text { Total }\end{array}$} & $<14$ & 111 & 8.29 & 2.99 & 0.28 & 7.73 & 8.85 \\
\hline & $15-29$ & 203 & 8.11 & 3.19 & 0.22 & 7.67 & 8.55 \\
\hline & $30-49$ & 328 & 8.59 & 3.24 & 0.18 & 8.24 & 8.94 \\
\hline & $50-64$ & 160 & 8.63 & 3.36 & 0.27 & 8.10 & 9.15 \\
\hline & $65-84$ & 38 & 7.92 & 3.58 & 0.58 & 6.74 & 9.10 \\
\hline & Total & 840 & 8.41 & 3.24 & 0.11 & 8.19 & 8.63 \\
\hline
\end{tabular}

Before the COVID-19 pandemic there was no difference in physical activity by gender. Males and females reported $1024 \pm 1290$ and $1019 \pm 1437$ average weekly minutes, respectively, their variances were equal $(p=0.429)$ and difference was not significant $(p=0.955)$; however, when the pandemic struck differences and changes became significant, possibly due to different gender roles in society. Physical activity of men in the sport sector decreased by an average of $133 \pm 1092$ minutes per week, whilst that of women decreased by $286 \pm 980$ minutes, and although variances remained equal $(\mathrm{p}=0.480)$, the difference in gender was significant $(\mathrm{p}=0.036)$. It is even more interesting to analyze the outcome as variance of physical activity of men and women became unequal $(\mathrm{p}=0.008)$ and the difference in gender was significant $(\mathrm{p}=0.045)$ with men being more physically active during the COVID-19 pandemic with a weekly average of $890 \pm 1144$ minutes, whilst women were only active for $733 \pm 1116$ minutes in the same period.

The well-being score observed during the pandemic was $8.59 \pm 3.28$ for men and $8.19 \pm 3.18$ for women, but the difference was not significant $(\mathrm{p}=0.074)$ and the variances were equal $(\mathrm{p}=0.723)$.

When considering education, there were no significant differences across respondents with different educational levels (grammar school, technical school, secondary school, college/university) in the change of physical activity level during the COVID-19 pandemic $(p=0.492)$, although the weekly decrease of those with a college or university degree was $99 \pm 982$ minutes, which is less than half that of all other educational groups

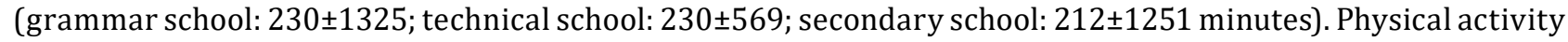
before the COVID-19 pandemic was significantly different according to level of education ( $p=0.003)$ as well as under the COVID-19 pandemic ( $p=0.018)$; their averages can be seen in Table 4.

Mental well-being in the sport sector is very interesting as there was no significant difference among the different educational levels $(\mathrm{p}=0.167)$, although the means gradually increased by educational level (see Table 4). Even if we change the scope to graduates and non-graduates, the difference is still insignificant, although it is approaching statistical significance $(\mathrm{p}=0.056)$. If we compare the different educational levels with graduates,

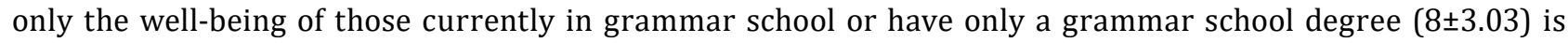
significantly different $(p=0.030)$ than the well-being of graduates $(8.65 \pm 3.29)$.

Table 4. Physical activity and well-being by education in the sport sector

\begin{tabular}{|c|c|c|c|c|c|c|c|}
\hline \multirow{2}{*}{$\begin{array}{c}\text { IPAQ and WHO-5 Scores by } \\
\text { Education }\end{array}$} & $\mathbf{N}$ & Mean & $\begin{array}{c}\text { Std. } \\
\text { Deviation }\end{array}$ & Std. Error & $\begin{array}{c}\text { 95\% Confidence Interval } \\
\text { for Mean }\end{array}$ \\
\cline { 4 - 9 } & & & & & Lower Limit & Upper Limit \\
\hline \multirow{4}{*}{$\begin{array}{c}\text { IPAQ Total } \\
\text { Change } \\
\text { (minutes per } \\
\text { week) }\end{array}$} & Grammar School & 167 & -229.78 & 1325.68 & 102.58 & -432.32 & -27.25 \\
\cline { 2 - 8 } & Technical School & 43 & -229.74 & 569.28 & 86.81 & -404.94 & -54.54 \\
\cline { 2 - 8 } & Secondary School & 258 & -212.67 & 1251.31 & 77.90 & -366.08 & -59.26 \\
\cline { 2 - 8 } & Graduate & 372 & -99.28 & 982.28 & 50.93 & -199.43 & 0.86 \\
\hline
\end{tabular}




\begin{tabular}{|c|c|c|c|c|c|c|c|}
\hline \multirow{5}{*}{$\begin{array}{l}\text { IPAQ Total } \\
\text { Before COVID } \\
\text { (minutes per } \\
\text { week) }\end{array}$} & Grammar School & 167 & 1060.00 & 1565.93 & 121.18 & 820.76 & 1299.24 \\
\hline & Technical School & 43 & 901.84 & 1097.19 & 167.32 & 564.17 & 1239.50 \\
\hline & Secondary School & 258 & 1257.24 & 1508.58 & 93.92 & 1072.29 & 1442.20 \\
\hline & Graduate & 372 & 852.20 & 1122.49 & 58.20 & 737.76 & 966.64 \\
\hline & Total & 840 & 1020.46 & 1352.97 & 46.68 & 928.83 & 1112.09 \\
\hline \multirow{5}{*}{$\begin{array}{c}\text { IPAQ Total } \\
\text { During COVID } \\
\text { (minutes per } \\
\text { week) }\end{array}$} & Grammar School & 167 & 830.22 & 1477.65 & 114.34 & 604.46 & 1055.97 \\
\hline & Technical School & 43 & 672.09 & 813.61 & 124.07 & 421.70 & 922.48 \\
\hline & Secondary School & 258 & 1044.58 & 1296.09 & 80.69 & 885.68 & 1203.48 \\
\hline & Graduate & 372 & 752.92 & 1031.11 & 53.46 & 647.80 & 858.05 \\
\hline & Total & 840 & 853.73 & 1211.34 & 41.80 & 771.70 & 935.77 \\
\hline \multirow{5}{*}{$\begin{array}{l}\text { WHO-5 Well- } \\
\text { Being Total }\end{array}$} & Grammar School & 167 & 8.00 & 3.03 & 0.23 & 7.54 & 8.46 \\
\hline & Technical School & 43 & 8.14 & 3.22 & 0.49 & 7.15 & 9.13 \\
\hline & Secondary School & 258 & 8.38 & 3.28 & 0.20 & 7.97 & 8.78 \\
\hline & Graduate & 372 & 8.65 & 3.29 & 0.17 & 8.32 & 8.99 \\
\hline & Total & 840 & 8.41 & 3.24 & 0.11 & 8.19 & 8.63 \\
\hline
\end{tabular}

According to marital status (single, in relationship, married) there was no significant difference in physical activity during the COVID-19 pandemic $(p=0.334)$ or mental well-being $(p=0.343)$, but, interestingly, there was significant difference before the pandemic $(\mathrm{p}<0.001)$. Singles and people in relationships were physically active for an average of $1106 \pm 1430$ and $1114 \pm 1600$ minutes a week, respectively, but those who were married were only active for $869 \pm 1061$ minutes.

Number of children did not result in any significant differences $(\mathrm{p}=0.230)$ across the different groups' $(0,1$, $2,3,4,4+$ children) physical activity or mental well-being $(\mathrm{p}=0.401)$. If we analyze only those who are 18 years or older (adult age in Hungary), then we see a significant difference in physical activity before the COVID-19 pandemic across the groups who have different numbers of children $(p=0.046)$, but this difference became insignificant $(p=0.083)$ during the pandemic, and there was no significant difference in well-being either $(\mathrm{p}=0.587)$.

Considering area of living, there were no significant differences in physical activity before $(p=0.553)$ or during the COVID-19 pandemic $(p=0.922)$, changes in physical activity because of the pandemic $(p=0.764)$, nor in mental well-being ( $\mathrm{p}=0.607)$.

The relationship between physical activity and well-being was measured by correlation analysis. Reported physical activity before the COVID-19 pandemic did not correlate with mental well-being during the pandemic ( $\mathrm{r}=0.057, \mathrm{p}=0.098)$, but reported physical activity during shows significant, positive correlation with mental well-being $(r=0.134, p<0.001)$ as well as the change in physical activity during the pandemic $(r=0.075, p=0.030)$. This is also supported by the results of the ANOVA test $(\mathrm{p}<0.001)$ which showed that those who did not decrease their physical activity during the COVID-19 pandemic experienced significantly better well-being (9.02 \pm 3.44$)$, as well as those who increased their physical activity (8.91 \pm 3.15$)$, than those who decreased their physical activity (8.04 \pm 3.21$)$.

\section{Discussion}

In the Hungarian sport sector, physical activity decreased significantly for elite or recreational athletes as a result of the COVID-19 pandemic, but there was no significant decrease in the physical activity of sport professionals. Sport professionals were the least physically active group before the pandemic, according to our results; therefore, we believe that they did not have much scope to decrease their activity, as they were already performing only the bare minimum. Physical activity of sport professionals was not bad at all, however, as their average physical activity was three times higher than the level recommended for staying healthy.

Younger generations had to change their lifestyle because of the COVID-19 pandemic much more than their elder compatriots, and it also significantly impacted their physical activity and sporting habits, as regular school based physical activity was absent, and regular trainings were also suspended. Under 14-year olds decreased their physical activity by 30\%, with which they became the least physically active age group in the Hungarian sport sector. This shows that although the decision makers created satisfactory alternatives in the case of grammar school learning, a satisfactory alternative for regular physical activity was missing. Were a second wave of the COVID-19 pandemic to arise, or any other similar lifestyle changing event were to happen, then physical activity of children should be an area of focus. 
Figure 1 shows the changes in physical activity and well-being by age groups in the sport sector. The lowest physical activity decrease was observed in the 30-49 age group, and they reported the second-highest wellbeing scores (8.59), slightly below the 50-64 age group (8.63).
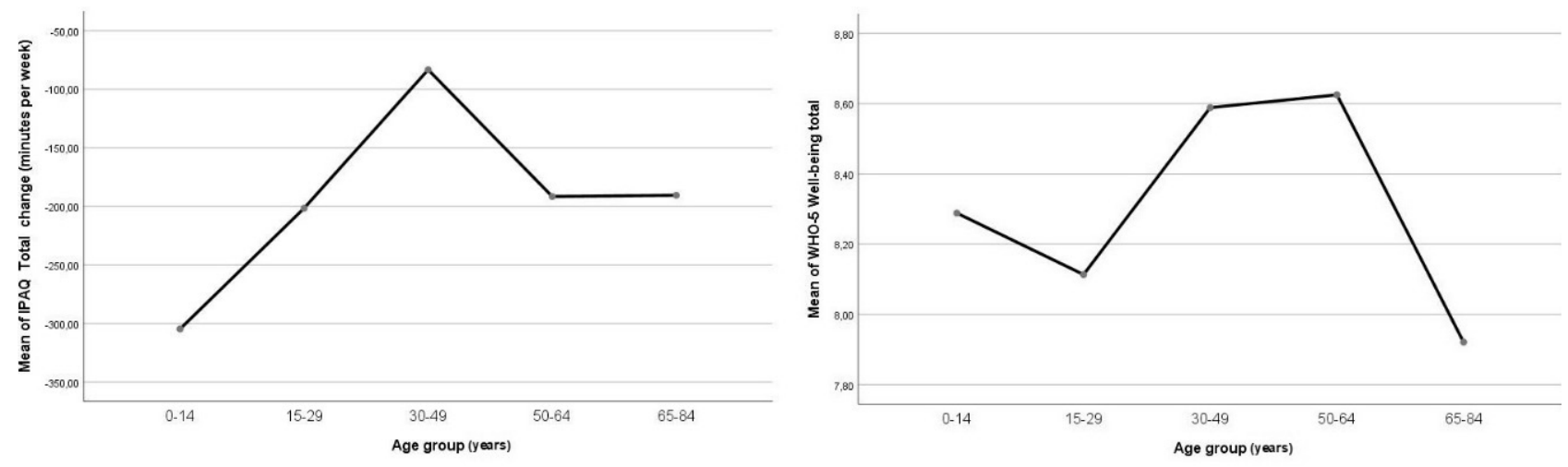

Figure 1. The changes in physical activity and well-being by age groups in the sport sector

Although physical activity decreased similarly in the 50-64 and 65-84 age groups, their well-being felt was very different (highest and lowest with 8.63 and 7.92 respectively), from which we can infer that in the oldest generations, non-sport related problems appear which decrease well-being, e.g., illnesses, decrease of income with retirement, etc.

According to physical activity by gender during quarantine, Cortis et al. shows that women $(6.0 \pm 3.9$ hours per week) exercise far less than men (8.3 \pm 4.4 hours per week) [18], whilst Sekulic et al. shows that physical activity of boys in South Croatia decreased more than girls [19]. These results are very different than what we observed in the Hungarian sport sector, where females decreased their physical activity significantly more than males did, and therefore the similar amount of physical activity before the pandemic changed in such a way that females became less physically active than males. We suspect that this is because the workload of women increased, with greater responsibility in home schooling and housework than men, which could have also contributed to the almost significantly $(\mathrm{p}=0.074)$ lower well-being felt by women. This shows that there must be greater emphasis on sharing these extra duties equally between males and females. People with higher degrees decreased their physical activity less than those with lower degrees, and their mental well-being seems to be better than non-graduates in the sport sector as well.

It is interesting to observe that the COVID-19 pandemic diminished physical activity differences caused by marital status and number of children; this is most probably due to the opportunities of those who had time to exercise before the pandemic becoming restricted. COVID-19 did not discriminate in terms of area of living; it did not matter whether people lived in urban or rural areas, their physical activity decreased similarly.

According to Yousfi et al. psychological comfort is especially important in challenging times like the COVID-19 pandemic, as home confinement can have harmful psychological consequences in athletes [20]. Our results show that those in the Hungarian sport sector who exercise the most, or could even increase their exercise level, experienced significantly greater well-being than those who did not during the pandemic. Therefore, we agree with the findings of Eirale et al in that training for maintaining physical fitness is important, but perhaps it is even more important to maintain psychological well-being. The method and the intensity of the training should be modified however to not increase risk of getting infected [1].

\section{Conclusions}

Physical activity changed significantly in Hungary because of the COVID-19 outbreak and the impacts of defensive measures against the pandemic. In the Hungarian sport sector, women and children decreased their physical activity the most, which had a negative impact on their well-being as well. Therefore, in significant lifestyle changing events such as this, decision makers should place more focus on physical activity, especially that of women and children.

People with higher degrees and in their middle ages were more resistant to the changes caused by the COVID-19 pandemic, most probably because their jobs were easier to adapt, and their lifestyles were more conscious. Graduates' mental well-being seemed to be better than non-graduates.

Even in the Hungarian sport sector, where the most physically active members of the Hungarian society are, in significant lifestyle changing events like the COVID-19 pandemic, the more physically active people are, the 
greater their well-being. Therefore, promotion of physical activity becomes even more important in challenging times.

\section{Disclosures and acknowledgements}

We would like to thank the representatives of Hungarian Sport Associations for distributing our questionnaire to their members.

\section{References:}

1. Eirale C, Bisciotti G, Corsini A, Baudot C, Saillant G, Chalabi H. Medical recommendations for home-confined footballers' training during the COVID-19 pandemic: from evidence to practical application. Biology of Sport. 2020; 37(2): 203-207. https://doi.org/10.5114/biolsport.2020.94348

2. Mann RH, Clift BC, Boykoff J, Bekker S. Athletes as community; athletes in community: Covid-19, sporting mega-events and athlete health protection. Br J of Sports Med. Forthcoming 2020. https://doi.org/10.1136/bjsports-2020-102433

3. Parnell D, Widdop P, Bond A, Wilson R. COVID-19, networks and sport. Managing Sport and Leisure. Forthcoming 2020. https://doi.org/10.1080/23750472.2020.1750100

4. Gallego V, Nishiura H, Sah R, Rodriguez-Morales A. The COVID-19 outbreak and implications for the Tokyo 2020 Summer Olympic Games. Travel Medicine and Infectious Disease. 2020; 34: 101604. https://doi.org/10.1016/j.tmaid.2020.101604

5. Ács P, Kovács A, Paar D, Hoffbauer M, Szabo P, Szabo T, et al. Comparative analysis of the economic burdens of physical inactivity in Hungary between 2005-2017. BMC Public Health. Forthcoming 2020. https://doi.org/10.1186/s12889-020-08478-y

6. Yan Z, Spaulding HR. Extracellular superoxide dismutase, a molecular transducer of health benefits of exercise. Redox Biology. 2020; 32: May 2020, 101508. https://doi.org/10.1016/j.redox.2020.101508

7. Lippi G, Henry BM, Bovo C, Sanchis-Gomar F. Health risks and potential remedies during prolonged lockdowns for coronavirus disease 2019 (COVID-19). Diagnosis. 2020; 7(2): 85-90.

https://doi.org/10.1515/dx-2020-0041

8. Burtscher J, Burtscher M, Millet GP. (Indoor) isolation, stress and physical inactivity: vicious circles accelerated by Covid-19?. Scandinavian Journal of Medicine \& Science in Sports. Forthcoming 2020. https://doi.org/10.1111/sms.13706

9. Björk J, Albin M, Grahn M, Jacobsson H, Ardö J, Wadbro J, et al. Recreational values of the natural environment in relation to neighbourhood satisfaction, physical activity, obesity and wellbeing. Journal of Epidemiology and Community Health. 2008; 62: e2. https://doi.org/10.1136/jech.2007.062414

10. Brajsa-Zganec A, Merkas M, Sverko I. Quality of life and leisure activities: how do leisure activities contribute to subjective well-being?. Social Indicator Research. 2011; 102: 81-91. https://doi.org/10.1007/s11205-010-9724-2

11. Kökény L, Kiss K. [Sound mind in a sound body - the connection of sports and wellbeing]. In: Józsa L, Korcsmáros E, Seres Huszárik E., editors. [Efficient marketing - Proceedings of the International Scientific Conference EMOK 2018]. Komárom: Selye János Egyetem; 2018. p. 969-978 (in Hungarian).

12. koronavirus.gov.hu [Internet]. 2020 March 20. [Most dangerous to elderly and people suffering chronic diseases, but younger generations can be infected as well] [cited 2020 March 20]. Available from: https://koronavirus.gov.hu/cikkek/az-idosek-es-kronikus-betegek-szamara-legnagyobb-veszely-defiatalok-elkaphatjak (in Hungarian).

13. Hungarian Central Statistical Office. [On-line database of the Hungarian Statistical Office] [Internet]. Budapest: Hungarian Central Statistical Office; 2020 [cited 2020 Jun 25]. Available from: http://statinfo.ksh. hu/Statinfo/haViewer.jsp (in Hungarian).

14. Susánszky É, Konkoly-Thege B, Stauder A, Kopp M. [Validating the Hungarian version of WHO well-being questionnaire (WBI-5) with Hungarostudy 2002 domestic health survey]. Mentálhigiéné és Pszichoszomatika. 2006; 7(3): 247-255 (in Hungarian). https://doi.org/10.1556/Mental.7.2006.3.8

15. Dinyáné SM, Pusztai G. Use of the short (5-item) version of the WHO well-being questionnaire in first year students of Semmelweis University. Orvosi Hetilap. 2016; 157(44): 1762-1768. https://doi.org/10.1556/650.2016.30572

16. McMahon EM, Corcoran P, O'Regan G, Keeley H, Cannon M, Carli V, et al. Physical activity in European adolescents and associations with anxiety, depression and well-being. European Child \& Adolescent Psychiatry. 2017; 26(1): 111-122. https://doi.org/10.1007/s00787-016-0875-9 
17. Ács P. [Data analysis in practice]. Pécs: PTE-ETK; 2014 (in Hungarian).

18. Cortis C, Giancotti GF, Rodio A, Bianco A, Fusco A. Home is the new gym: exergame as a potential tool to maintain adequate fitness levels also during quarantine. Human Movement. 2020; 21(4): $79-87$. https://doi.org/10.5114/hm.2020.94826

19. Sekulic D, Blazevic M, Gilic B, Kvesic I, Zenic N. Prospective analysis of levels and correlates of physical activity during COVID-19 pandemic and imposed rules of social distancing; gender specific study among adolescents from southern Croatia. Sustainability. 2020,12(10): 4072. https://doi.org/10.3390/su12104072

20. Yousfi N, Bragazzi NL, Briki W, Zmijewski P, Chamari K. The COVID-19 pandemic: how to maintain a healthy immune system during the lockdown - a multidisciplinary approach with special focus on athletes. Biol Sport. 2020; 37(3): 211-216. https://doi.org/10.5114/biolsport. 2020.95125 